\title{
Hydrophobically Directed Aldol Reactions: Polystyrene-Supported L-Proline as a Recyclable Catalyst for Direct Asymmetric Aldol Reactions in the Presence of Water
}

\author{
Michelangelo Gruttadauria, ${ }^{*[a]}$ Francesco Giacalone, ${ }^{[a]}$ Adriana Mossuto Marculescu, ${ }^{[a]}$ \\ Paolo Lo Meo, ${ }^{\text {[a] }}$ Serena Riela, ${ }^{\text {[a] }}$ and Renato Noto ${ }^{[a]}$
}

\author{
Dedicated to Professor Domenico Spinelli on the occasion of his 75 th birthday
}

Keywords: Alcohols / Enantioselectivity / Ketones / Organocatalysis / Polymers

A simple synthetic methodology for the preparation of a polystyrene-supported L-proline material is reported, and this material has been used as catalyst in direct asymmetric aldol reactions between several ketones and arylaldehydes to furnish aldol products in high yields and stereoselectivities. Screening of solvents showed that these reactions take place only in the presence of water or methanol, at lower levels of conversion in the latter case. This solvent effect, coupled with the observed high stereoselectivities, has been ex- plained in terms of the formation of a hydrophobic core in the inner surface of the resin, whereas the hydrophilic proline moiety lies at the resin/water interface. Such a microenvironment both promotes the aldol reaction and increases the stereoselectivity. Recycling investigations have shown that this material can be reused, without loss in levels of conversion and stereoselectivity, for at least five cycles.

(@ Wiley-VCH Verlag GmbH \& Co. KGaA, 69451 Weinheim, Germany, 2007)

\section{Introduction}

In the last decade organocatalysis has became a field of great interest. ${ }^{[1]}$ Organocatalysts are metal-free small organic molecules that are able to function as efficient and selective catalysts for a large variety of enantioselective transformations. In this context, L-proline and its derivatives have emerged as powerful organocatalysts. ${ }^{\left[{ }^{2]}\right.}$ L-Proline can be regarded as the simplest "enzyme" and it has been successfully applied in many reactions, such as Robinson annulations, ${ }^{[3]}$ aldol reactions, ${ }^{[4]}$ Mannich reactions, ${ }^{[5]}$ Michael reactions, ${ }^{[6]}$ direct electrophilic $\alpha$-aminations, ${ }^{[7]} \mathrm{Di}$ els-Alder reactions, ${ }^{[8]}$ Baylis-Hillman reactions, ${ }^{[9]}$ aza-Morita-Baylis-Hillman reactions, ${ }^{[10]} \alpha$-selenenylation, ${ }^{[11]}$ oxidation, ${ }^{[12]}$ chlorination, ${ }^{[13]}$ and others. ${ }^{[14]}$

Among all these processes, L-proline-mediated aldol reactions affording $\beta$-hydroxy ketones have been investigated in great depth. Indeed, the aldol reaction is one of the most important $\mathrm{C}-\mathrm{C}$ bond-formation methods in organic synthesis. ${ }^{[15]}$ Proline and its derivatives operate by bifunctional catalysis and play the role of a simplified version of the type I

[a] Dipartimento di Chimica Organica "E.Paternò", Università di Palermo,

Viale delle Scienze, Pad. 17, 90128 Palermo, Italy

Fax: +39-091-596825

E-mail:mgrutt@unipa.it aldolase enzymes, ${ }^{[16]}$ promoting the formation of an enamine and its enantioselective condensation with an aldol acceptor. Such L-proline-catalyzed aldol reactions are usually carried out in organic solvents such as DMSO, DMF, or chloroform. The extent of enantioselectivity in the reaction was found to be dependent on the solvent system used; dimethyl sulfoxide was reported to be the solvent of choice. ${ }^{[4 a]}$ However, the recovery of the catalysts and the separation of the products are major disadvantages in the homogeneous catalytic process. Moreover, the organocatalyst is usually used in substantial quantity, in the case of Lproline up to $30 \mathrm{~mol}-\%$. For this reason efficient recovery and reuse of the organocatalyst have became major concerns. ${ }^{[17]}$

Several methods for L-proline recovery have been investigated. Immobilization by adsorption on silica gel gave poor enantiomeric excess values, ${ }^{[4]}$ but good results have been reported for the use of $\mathrm{L}$-proline in ionic liquids as reusable catalysts for aldol reactions. ${ }^{[18]} \mathrm{BmimPF}_{6}$ was the ionic liquid of choice, though recycling studies showed slightly diminished yields and ee values. Excellent results were obtained in the cross-aldol reaction. ${ }^{[19]}$ More recently, an ionic liquid-anchored $(2 S, 4 R)$-4-hydroxyproline was prepared. ${ }^{[20]}$ This molecule catalyzed the direct asymmetric aldol reaction in neat acetone or butan-2-one with enantioselectivity superior to that afforded by L-proline. The catalyst was easily recovered and reused for at least four times with un- 
changed results. Recycling of proline and solvent was possible over up to ten runs without loss of activity when the reaction was carried out in PEG-400. ${ }^{[21]}$

We have reported the use of supported ionic liquids as new recyclable materials for the L-proline-catalyzed aldol reaction. ${ }^{[22]}$ In our case, proline was adsorbed onto ionic liquid-modified silica gel with or without additional adsorbed ionic liquid. These catalytic systems gave good yields and ee values and were easily recovered and reused.

In addition to these examples, L-proline was also anchored to a support. Good yields and ee values were obtained with polyethylene glycol supported proline. ${ }^{[23]} \mathrm{Up}$ to four cycles were reported with unchanged $e e$ values, but in slowly diminishing yields. Low ee values were observed in reactions with proline immobilized on polyethylene glycol grafted onto cross-linked polystyrene in aqueous media, while higher ee values were obtained with polymer-supported peptide. ${ }^{[24]}$ Proline immobilized on a mesoporous support was used in asymmetric aldol reactions of hydroxyacetone with aldehydes. ${ }^{[25]}$

These reactions, under both homogeneous and heterogeneous conditions, are usually carried out in DMSO, DMF, acetone, chloroform, and - in selected examples in $\mathrm{DMSO} / \mathrm{H}_{2} \mathrm{O}$ or $\mathrm{DMF} / \mathrm{H}_{2} \mathrm{O}$. Indeed, addition of water may improve enantioselectivities. ${ }^{[26]}$ However, the use of a large amount of water resulted in the formation of products with low or no enantioselectivity. ${ }^{[4 \mathrm{~b}, 27]}$ Recently, highly diastereo- and enantioselective direct aldol reactions in water in the presence of proline bearing large apolar substituents or amine catalysts bearing hydrophobic alkyl chains have been reported. ${ }^{[28]}$ Such molecules are better mimics than unmodified proline since natural Class I aldolase enzymes use an enamine mechanism in water. The authors hypothesized that these catalysts should assemble with hydrophobic reactants in water and sequester the transition state from water.

Since the substrates are insoluble in water, a debate is now open as to whether some of these reactions really are "all wet". [29] Hayashi has proposed that these reactions might be better considered as carried out "in the presence of water". ${ }^{30]}$ On the other hand, Blackmond has raised doubts about the greenness of organocatalytic reactions carried out in the presence of water. ${ }^{[31]}$

In this context, our research is addressed towards two major objectivies: (1) the synthesis of a polystyrene-supported L-proline and its use as an enzyme-like catalyst in the direct asymmetric aldol reaction in the presence of water and (2) recycling investigations into such heterogeneous catalytic materials.

\section{Results and Discussion}

We had previously reported preliminary results on the use of a polystyrene-supported L-proline as an efficient and recyclable catalyst both for enantioselective aldol reactions in water without additives and for $\alpha$-selenenylation of aldehydes. ${ }^{[32]}$ Recently, Pericàs ${ }^{[33]}$ et al. published a paper deal- ing with asymmetric aldol reactions in water based on the use of a polystyrene-supported proline. The L-proline was anchored to a polystyrene resin through a 1,2,3-triazole moiety and this catalyst was used for the aldol reaction in water, giving high stereoselectivities, whereas yields were increased by using 10 mol- $\%$ of DiMePEG as additive.

In our case a different synthetic strategy was followed in order to obtain the polystyrene-supported L-proline. Commercially available trans- $N$-Boc-4-hydroxy-L-proline was used for proline immobilization since its hydroxy group can be easily functionalized. As support we chose the commercially available mercaptomethyl-functionalized polymer shown in Scheme 1 ( $1 \%$ cross-linked with DVB, spherical beads, particle size 100-200 mesh, $2.5 \mathrm{mmol}$ per gram loading). Anchorage of L-proline was accomplished in two steps (Scheme 1): (1) synthesis of hydroxy-L-proline styrene derivative 1 and (2) radical reaction between the polystyrene and 1 followed by deprotection of the proline moiety. The removal of the tert-butoxycarbonyl group was carried out with $\mathrm{TFA} / \mathrm{CH}_{2} \mathrm{Cl}_{2}$ (20:80), followed by treatment with $\mathrm{Et}_{3} \mathrm{~N} / \mathrm{MeOH}(2: 98)$.

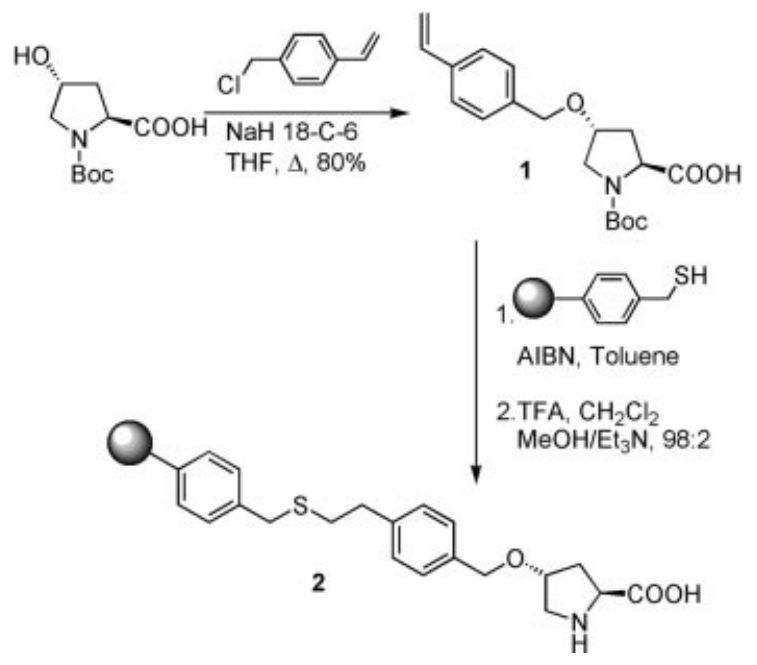

Scheme 1. Synthesis of the polystyrene-supported L-proline catalyst.

This procedure gave the polystyrene-supported L-proline in high yield and in a very simple way (proline loading ca. $1.4 \mathrm{mmolg}^{-1}$, as determined by elemental analysis and weight gain). The resin was characterized by elemental analysis and solid state ${ }^{13} \mathrm{C}$ NMR and IR spectroscopy. Figure 1 shows the ${ }^{13} \mathrm{C}$ MAS NMR spectrum of $N$-Boc-protected resin 2, while Figures 2 and 3 show ${ }^{13} \mathrm{C}$ MAS NMR and IR spectra, respectively, of deprotected resin 2 . The presence of signals in the aliphatic region confirmed the anchorage of the proline moiety. Moreover, a comparison between ${ }^{13} \mathrm{C}$ MAS NMR spectra before and after deprotection showed the almost complete disappearance of the Boc group at $\delta=29$ ppm and the IR spectrum showed the typical pattern of an amino acid. Figure 4 shows a SEM micrograph of resin 2 .

As a first approach we tested our catalyst under the conditions used by Hayashi ${ }^{[28 b]}$ (aldehyde $0.4 \mathrm{mmol}$; cyclohexa- 


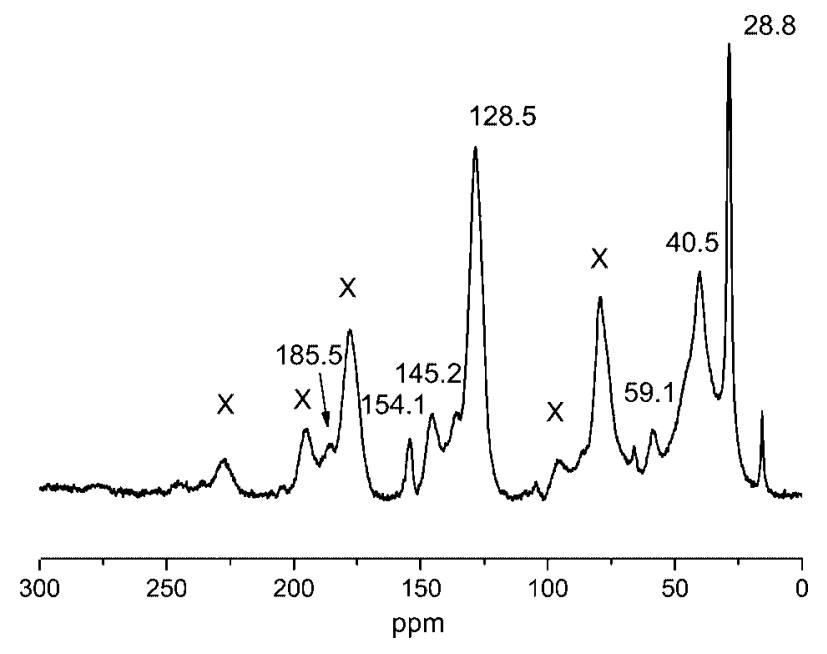

Figure $1 .{ }^{13} \mathrm{C}$ MAS NMR spectrum of $N$-Boc-protected resin. Side bands (x).

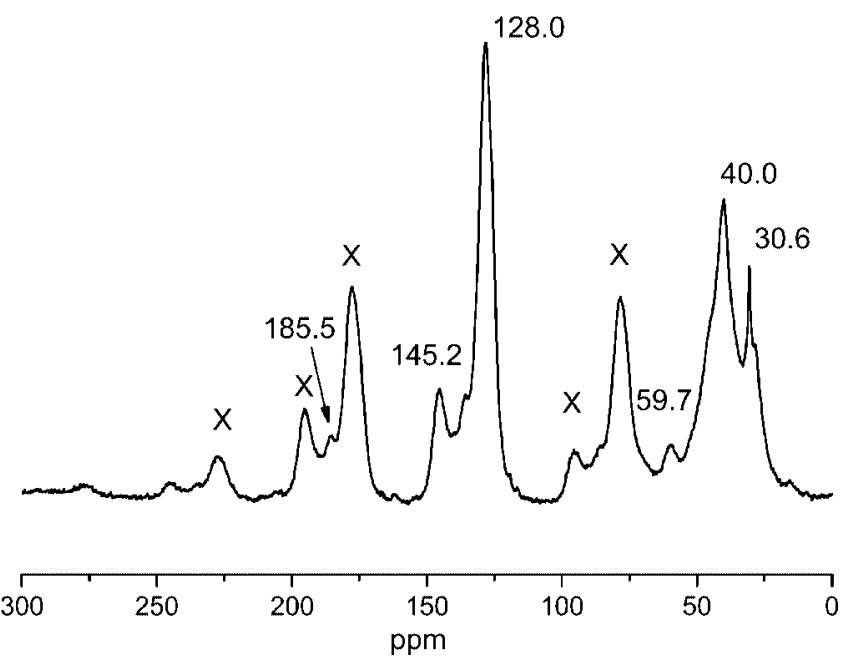

Figure 2. ${ }^{13} \mathrm{C}$ MAS NMR spectrum of resin 2. Side bands (x).

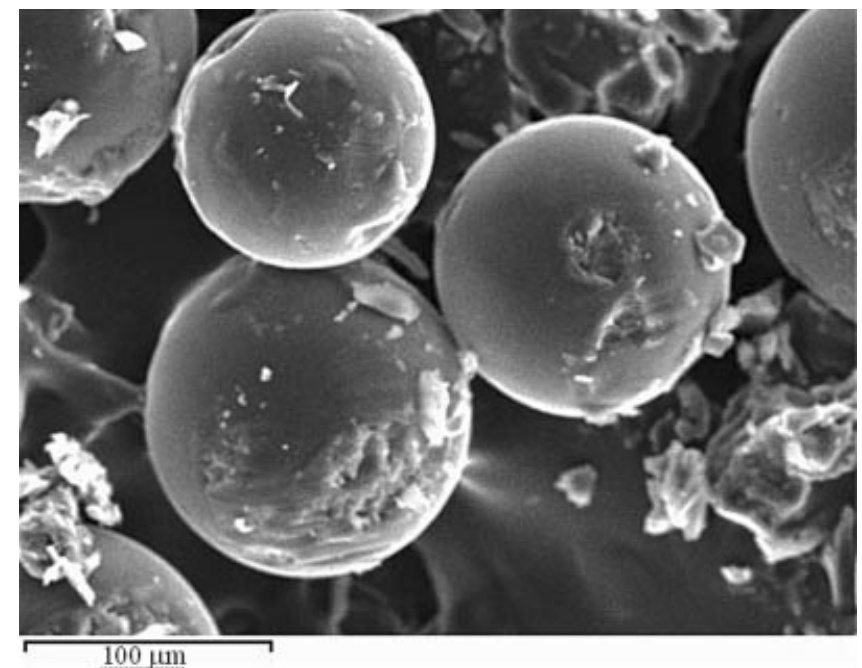

Figure 4. SEM micrograph of polystyrene-supported proline $\mathbf{2}$.

none $2.0 \mathrm{mmol}$; catalyst $0.04 \mathrm{mmol} ; \mathrm{H}_{2} \mathrm{O} 0.14 \mathrm{~mL}$ ), using $p$ cyanobenzaldehyde as acceptor (Table 1, Entry 1). The reaction worked nicely in the presence of water, giving the aldol product in almost quantitative yield and with high diastereoselectivity and high ee value. The use of larger amounts of water (200 or $400 \mu \mathrm{L}$; Table 1, Entries 2 and 3) yielded the aldol product with decreased levels of conversion, but still with high diastereoselectivity and ee value. Very interestingly, the reaction did not work in the absence of water (Table 1, Entry 4).

This results prompted us to investigate the solvent effect on the aldol reaction (Table 2). A solvent screening gave interesting results. The reaction did not work either in polar aprotic solvents (DMSO, DMF; Table 2, Entries 1 and 2) or in apolar solvents (dioxane, chloroform; Table 2, Entries 3 and 4). The use of polar protic solvents $(\mathrm{MeOH}$, EtOH, $i$-PrOH; Table 2, Entries 6-8) showed decreased

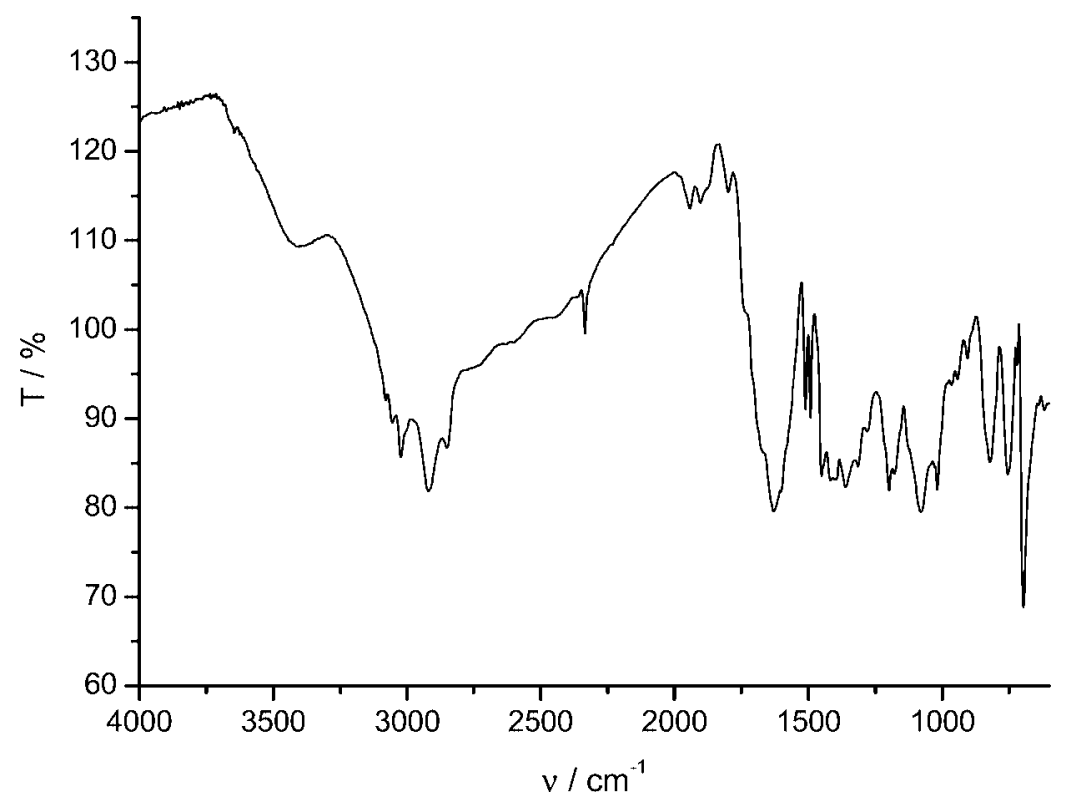

Figure 3. IR spectrum of resin 2. 
Table 1. The effect of amount of water on the reaction yield and selectivity. ${ }^{[a]}$

\begin{tabular}{|c|c|c|c|c|c|c|}
\hline Entry & $\begin{array}{c}\text { Water } \\
{[\mu \mathrm{L}]}\end{array}$ & $\begin{array}{c}\text { Time } \\
{[\mathrm{h}]}\end{array}$ & $\begin{array}{c}\text { Conv. } \\
{[\%]}\end{array}$ & $\begin{array}{c}\text { Yield } \\
{[\%]}\end{array}$ & anti/syn ${ }^{[\mathrm{b}]}$ & $\begin{array}{l}e e^{[\mathrm{c}]} \\
{[\%]}\end{array}$ \\
\hline 1 & 140 & 22 & 98 & 93 & $95: 5$ & 98 \\
\hline 2 & 200 & 22 & 80 & 76 & $95: 5$ & 98 \\
\hline 3 & 400 & 22 & 67 & 64 & $96: 4$ & 98 \\
\hline 4 & 0 & 22 & $<5$ & - & nd & nd \\
\hline
\end{tabular}

[a] Reaction conditions: cyclohexanone $(207 \mu \mathrm{L}, 2.0 \mathrm{mmol})$, aldehyde $(0.4 \mathrm{mmol})$, catalyst $(0.04 \mathrm{mmol}), \mathrm{H}_{2} \mathrm{O}$ at room temperature. [b] Determined by ${ }^{1} \mathrm{H}$ NMR spectroscopic analysis of the crude product. [c] Determined by HPLC using a chiral column.

levels of conversion on going from methanol to $i$-PrOH. In methanol, stereoselectivity was comparable with that observed in water, while lower diastereoselectivity was observed in ethanol.

Table 2. Solvent effect on the aldol reaction between cyclohexanone and $p$-nitrobenzaldehyde. ${ }^{[a]}$

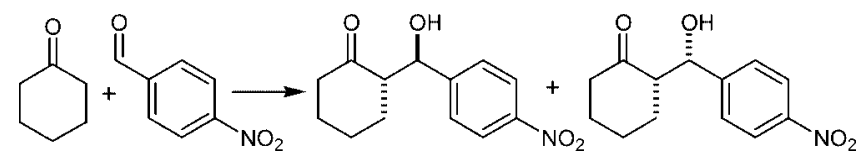

\begin{tabular}{llccccc}
\hline Entry & Solvent & $\begin{array}{c}\text { Time } \\
{[\mathrm{h}]}\end{array}$ & $\begin{array}{c}\text { Conv. } \\
{[\%]}\end{array}$ & $\begin{array}{c}\text { Yield } \\
{[\%]}\end{array}$ & $\begin{array}{c}\text { anti/syn } \\
{[\mathrm{b}]}\end{array}$ & $\begin{array}{c}e e^{[\mathrm{c}]} \\
{[\%]}\end{array}$ \\
\hline 1 & DMSO & 22 & $\mathrm{nr}$ & - & - & - \\
2 & DMF & 22 & $\mathrm{nr}$ & - & - & - \\
3 & dioxane & 22 & $\mathrm{nr}$ & - & - & - \\
4 & $\mathrm{CHCl}$ & 22 & $\mathrm{nr}$ & - & - & - \\
5 & $\mathrm{H}_{2} \mathrm{O}$ & 22 & 85 & 82 & $95: 5$ & 98 \\
6 & $\mathrm{MeOH}$ & 22 & 42 & 40 & $95: 5$ & 95 \\
7 & $\mathrm{EtOH}$ & 22 & 12 & 10 & $88: 12$ & $\mathrm{nd}$ \\
8 & $i \mathrm{PrOH}$ & 22 & $\mathrm{nr}$ & - & - & - \\
9 & $\mathrm{DMSO}^{2} \mathrm{H}_{2} \mathrm{O}^{[\mathrm{d}]}$ & 22 & 47 & 44 & $96: 4$ & 98 \\
10 & $\mathrm{CHCl}_{3} / \mathrm{H}_{2} \mathrm{O}^{[\mathrm{d}]}$ & 22 & 48 & 44 & $97: 3$ & 98 \\
\hline
\end{tabular}

[a] Reaction conditions: cyclohexanone $(207 \mu \mathrm{L}, 2.0 \mathrm{mmol})$, aldehyde $(0.4 \mathrm{mmol})$, catalyst $(0.04 \mathrm{mmol})$, solvent $(140 \mu \mathrm{L})$ at room temperature. [b] Determined by ${ }^{1} \mathrm{H}$ NMR spectroscopic analysis of the crude product. [c] Determined by HPLC using a chiral column. [d] DMSO or $\mathrm{CHCl}_{3} 120 \mu \mathrm{L}, \mathrm{H}_{2} \mathrm{O} 20 \mu \mathrm{L}$.

In order to ascertain the crucial role played by water, we carried out the reaction both in DMSO/water and in chloroform/water. In both cases the reaction took place with excellent stereoselectivity, although at lower levels of conversion. Water thus appears to be the optimal medium for the reaction even if substrates are not soluble.

Next, a representative set of aldehydes was examined. Reactions were carried out in the presence of water. Interestingly, aromatic aldehydes gave excellent results, with reaction times ranging between 22 and $120 \mathrm{~h}$. Low levels of conversions were observed only in the cases of the more sterically hindered $\beta$-naphthaldehyde and the less reactive $p$-tolualdehyde. In the latter case, the slightly lower ee value observed may be due to electronic factors. ${ }^{[34]}$ Good-to-excel- lent levels of conversion were observed in the other cases. Diastereoselectivities (anti $>$ syn) and enantioselectivities were excellent in all cases except for that of furaldehyde, for which a lower diastereoselectivity was observed (85:15). It is interesting to note that aliphatic aldehydes did not react (Table 3, Entries 14-16).

Next, we examined reactions between different ketones and aldehydes. Reactions between cyclopentanone and $p$ cyano- or $p$-nitrobenzaldehyde gave the expected aldol products in excellent yields, and with diasteromeric ratios comparable with those observed with unsupported proline in aqueous media ${ }^{[28 a, 35]}$ and good ee values (Table 4, Entries 1 and 2). Again, in the absence of water, the reaction did not take place (Table 4, Entry 3). The reaction did not take place with cycloheptanone (Table 4, Entry 4) and so we tried different reaction conditions. We were delighted to find that the reaction worked nicely in chloroform/water as reaction medium.

Tetrahydro-4H-pyran-4-one gave excellent levels of conversion but lower stereoselectivity (Table 4, Entry 6). The lower $e e$ value may be ascribed to the increased water solubility of the ketone. In the case of tetrahydro- $4 H$-thiopyran4-one the usual reaction conditions gave low levels of conversion (11\%, Table 4, Entry 7) since this ketone is solid at room temperature The reaction carried out in $\mathrm{DMSO} /$ water $(170 \mu \mathrm{L} / 40 \mu \mathrm{L})$ gave the expected aldol with poor levels of conversion (33\%; Table 4, Entry 8). Searching for optimization conditions we found that the reaction worked well in chloroform as solvent with a stoichiometric amount of water $(7 \mu \mathrm{L}$, Table 4, Entry 9). We therefore again carried out the reaction between cyclohexanone and $p$-nitrobenzaldehyde, but in the presence of only $7 \mu \mathrm{L}$ of water (Table 4 , Entry 10), and found that such conditions furnished the aldol product in high levels of conversion and with excellent stereoselectivity.

The reaction with acetone was carried out with use of a large amount of ketone. In fact, with the usual amount of ketone very poor levels of conversion was obtained because of the high solubility of acetone in water. The levels of conversion was increased up to $28 \%$ by use of a $25: 1$ acetone/ aldehyde molar ratio (Table 4, Entry 11). However, the ee value was lower than that obtained under homogeneous conditions, again probably because of the solubility of acetone in water. In order to check whether enantioselectivity might be increased, we carried out the reaction in the absence of water. The level of conversion was indeed slightly higher, whereas the ee value was good (Table 4, Entry 12). Moreover, it should be pointed out that in this case the reaction took place in the absence of water. Then we investigated the behavior of butan-2-one under the same conditions as used in the reaction with acetone. Good levels of conversion were observed using a 25:1 ketone/aldehyde molar ratio. The regioselectivity was low, but high diastereoselectivity was observed. The reaction carried out in the absence of water gave low levels of conversion. Moreover, low regioselectivity and no diastereoselectivity were observed.

Finally, we carried out recycling studies (Table 5). The reactions were carried out on larger scales (aldehyde 
Table 3. Direct asymmetric aldol reactions between cyclohexanone and aldehydes in the presence of water, catalyzed by resin 2 $(10 \mathrm{~mol}-\%){ }^{[a]}$

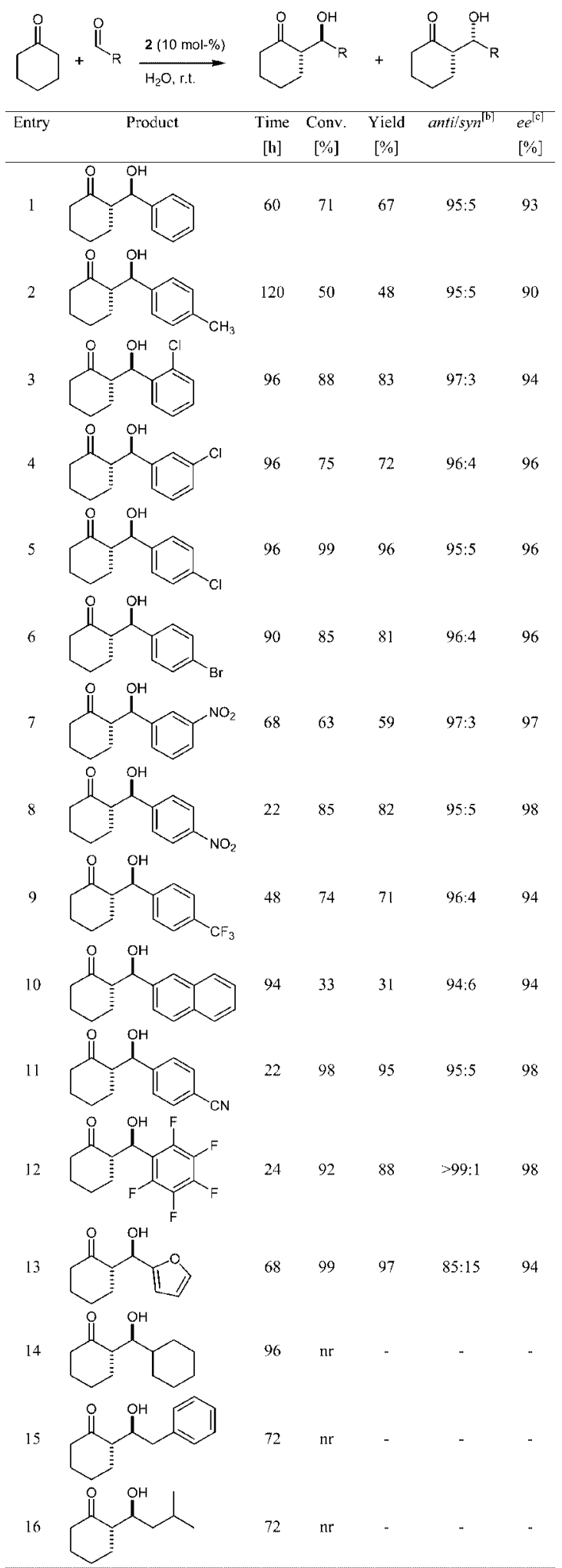

[a] Reaction conditions: cyclohexanone $(207 \mu \mathrm{L}, 2.0 \mathrm{mmol})$, aldehyde $(0.4 \mathrm{mmol})$, catalyst $(0.04 \mathrm{mmol}), \mathrm{H}_{2} \mathrm{O}(140 \mu \mathrm{L})$ at room temperature. [b] Determined by ${ }^{1} \mathrm{H}$ NMR spectroscopic analysis of the crude product. [c] Determined by HPLC using a chiral column.
Table 4. Direct asymmetric aldol reactions between ketones and aldehydes in the presence of water, catalyzed by resin $2(10 \mathrm{~mol}-\%){ }^{[\mathrm{a}]}$

[a] Reaction conditions: ketone $(2.0 \mathrm{mmol})$, aldehyde $(0.4 \mathrm{mmol})$, catalyst $(0.04 \mathrm{mmol}), \mathrm{H}_{2} \mathrm{O}(140 \mu \mathrm{L})$ at room temperature. [b] Determined from ${ }^{1} \mathrm{H}$ NMR spectroscopic analysis of the crude product. [c] Determined by HPLC using a chiral column. [d] Without water. [e] $\mathrm{CHCl}_{3} / \mathrm{H}_{2} \mathrm{O} 100 \mu \mathrm{L} / 40 \mu \mathrm{L}$. [f] DMSO/H $\mathrm{H}_{2} \mathrm{O} 170 \mu \mathrm{L} / 40 \mu \mathrm{L}$. [g] $\mathrm{CHCl}_{3} / \mathrm{H}_{2} \mathrm{O} 140 \mu \mathrm{L} / 7 \mu \mathrm{L}$. [h] Ketone/aldehyde molar ratio 25:1. [i] Regioisomeric ratio. 
$2 \mathrm{mmol}$ ), the resin was used five times with cyclohexanone and $p$-nitrobenzaldehyde, and the reactions were quenched by filtration. After each cycle the resin was washed with EtOAc and methanol and was then dried under vacuum at room temperature for a few minutes. Each cycle gave excellent anti/syn ratios and $e e$ values. Moreover, after five cycles no decrease in levels of conversion was observed. ${ }^{[36]}$

Table 5. Recycling studies. ${ }^{[\mathrm{a}]}$

\begin{tabular}{|c|c|c|c|c|c|c|}
\hline Entry & Cycle & $\begin{array}{c}\text { Time } \\
{[\mathrm{h}]}\end{array}$ & $\begin{array}{c}\text { Conv. } \\
{[\%]}\end{array}$ & $\begin{array}{l}\text { Yield } \\
{[\%]}\end{array}$ & anti/syn ${ }^{[\mathrm{b}]}$ & $\begin{array}{l}e e^{[c]} \\
{[\%]}\end{array}$ \\
\hline 1 & 1 & 22 & 85 & 82 & $95: 5$ & 98 \\
\hline 2 & 2 & 22 & 79 & 77 & $95: 5$ & 98 \\
\hline 3 & 3 & 22 & 82 & 80 & $95: 5$ & 98 \\
\hline 4 & 4 & 22 & 85 & 84 & $95: 5$ & 98 \\
\hline 5 & 5 & 22 & 88 & 85 & $95: 5$ & 98 \\
\hline
\end{tabular}

[a] Reaction conditions: cyclohexanone $(1.035 \mathrm{~mL}, 10.0 \mathrm{mmol})$, aldehyde $(2.0 \mathrm{mmol})$, catalyst $(0.2 \mathrm{mmol}), \mathrm{H}_{2} \mathrm{O}(700 \mu \mathrm{L})$ at room temperature. [b] Determined by ${ }^{1} \mathrm{H}$ NMR spectroscopic analysis of the crude product. [c] Determined by HPLC using a chiral column.

From a mechanistic point of view the crucial role played by water deserves more thorough comment. Such a role was evident when the reaction was carried out under neat conditions (Table 1, Entry 4). Indeed, in contrast with the data reported by Pericás, water seems to be essential. Apart from water, only methanol was able to promote the reaction. Experimental evidence indicates that water influences the reaction rate. ${ }^{[37]}$ Acceleration of organic reactions through aqueous solvent effects is a well known phenomenon. ${ }^{[38]}$ Water may play several roles in the proline-catalyzed aldol process: it might assist in the hydrolysis of the intermediate oxazolidinones that might be forming from the aldehyde, ketone, or the product. Alternatively, water might promote faster hydrolysis of the intermediates of the enamine catalytic cycle (Scheme 2). ${ }^{[4 e, 26,39]}$ Moreover, a small excess of water facilitates proton transfer in the transition state, lowering the LUMO of the incoming electrophile. ${ }^{[4 e]}$ However, it should be remembered that beneficial effects of water molecules are observed when water is added as cosolvent up to $300 \mathrm{~mol}-\%$. The use of larger amounts of water usually gives racemic products. In our case, the polystyrenesupported proline behaves as a proline substituted with a large apolar substituent, allowing its use in water.

On the other hand, the fact that no reaction is observed in DMSO or DMF is very unusual. We believe that solvents reported in Table 2 do not promote the reaction simply because they are good solvents. Ketones and aldehydes are well dissolved, while the catalytic center is supported on a material having a very low surface area. This strongly favors the repartition of the reactants in the liquid phase. When water is used as reaction medium, reactants are forced into the hydrophobic pocket of the resin. In other words, the reaction proceeds in a concentrated organic phase.
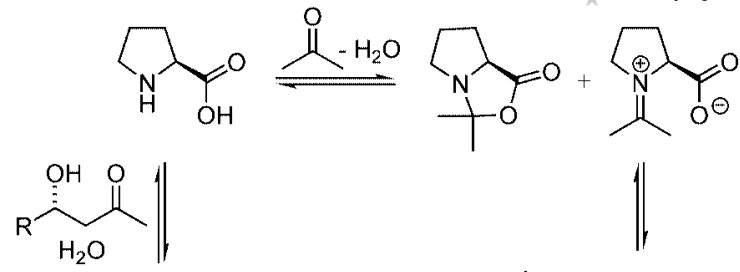<smiles>C=CC=C</smiles>

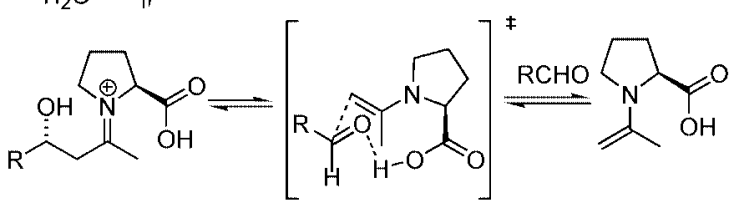

Scheme 2. Mechanism for the L-proline-catalyzed aldol reaction.

We hypothesize that the hydrophilic proline moiety lies at the interface $\left(\mathrm{resin} / \mathrm{H}_{2} \mathrm{O}\right)$, which facilitates the formation of a hydrophobic core on the inner surface of the resin (Figure 5). Such a microenvironment promotes the aldol reaction with high stereoselectivity. ${ }^{[40]}$ It is worth noting that even a stoichiometric amount of water seems to promote the aldol reaction in high yield and stereoselectivity. The different reaction rates observed when the reactions are carried out in pure cyclohexanone or in acetone are ascribed to the fact that cyclic ketones react much more slowly in the proline-catalyzed aldol reactions. ${ }^{[2 \mathrm{c}, 4 \mathrm{a}, 4 \mathrm{~b}, 41]}$

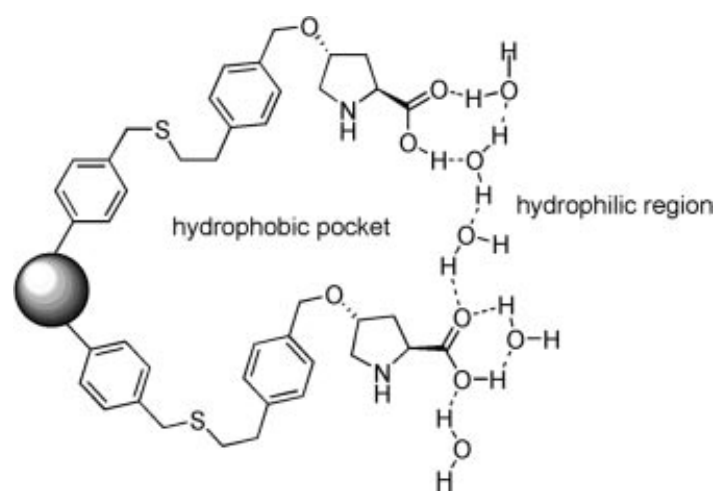

Figure 5. Proposed structure of the polystyrene-supported proline in the presence of water.

Under homogeneous conditions, the reaction usually yields the aldol product in low diastereomeric ratio. For example, the reaction between cyclohexanone and p-nitrobenzaldehyde in DMSO gave a 63:37 anti/syn ratio. ${ }^{[28 a]}$ When the reaction was carried out with modified L-proline in the presence of water the diastereoselectivity ratio was as high as 95:5. ${ }^{[28 b]}$ In our case the high diastereomeric ratios observed can be explained as depicted in Figure 6. Quantum mechanical calculations have predicted the transition state geometries for the reaction of cyclohexanone enamine with benzaldehyde. ${ }^{[41]}$ Following this mechanism we hypothesize that transition state $\mathbf{A}$ is highly stabilized because the hydrophobic aldehyde lies in the inner hydrophobic region, while transition state $\mathbf{B}$ is destabilized because the hydrophobic part of the aldehyde is directed towards the 
outer hydrophilic region. Such hydrophobic interactions have been used to explain improved selectivities on transition from organic to aqueous solvents. ${ }^{[42]}$

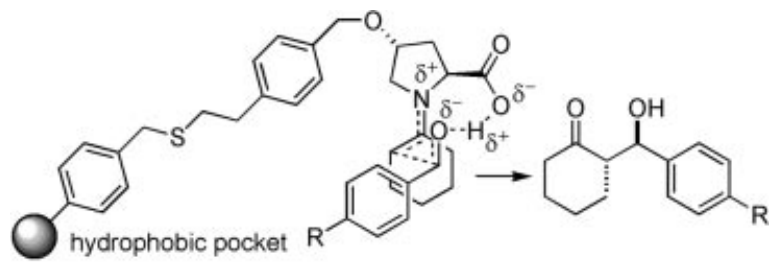

A

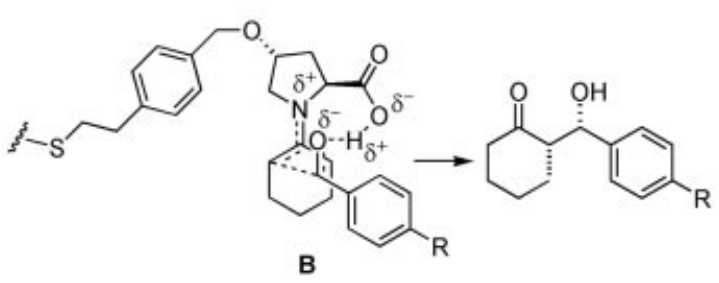

Figure 6. Proposed transition state model for the major stereoisomer (A) and the minor stereoisomer (B).

With a more hydrophobic aldehyde, such as pentafluorobenzaldehyde, higher diastereoselectivity was observed, while lower diastereoselectivity was observed with the more hydrophilic furfuraldehyde. Moreover, lower stereoselectivities were observed with more hydrophilic ketones such us pyran-4-one or acetone. When acetone was used without water, the enantioselectivity was higher. A similar result can be seen in the case of butan-2-one. When the reaction was performed without water no diastereoselectivity was observed (Table 4, Entry 14), while excellent diastereoselectivity was observed in the presence of water (Table 4, Entry 13).

\section{Conclusions}

In summary, we have prepared a polystyrene-supported L-proline material by a simple synthetic methodology that yields the resin in two steps starting from commercially available mercaptomethyl-polystyrene. This material has been used as catalyst in direct asymmetric aldol reactions between several ketones and aryl aldehydes, without additives, to furnish aldol products in high yields and with stereoselectivities (diastereoselectivities up to 99:1, ee values up to $98 \%$ ) comparable to or even better than those observed under homogeneous conditions. Investigations into the reaction between cyclohexanone and $p$-nitrobenzaldehyde showed, unexpectedly, that solvents such as DMSO, $\mathrm{DMF}, \mathrm{CHCl}_{3}$, or dioxane did not promote the reaction. Water was able to promote the reaction variously as the sole reaction medium, or in mixtures with other solvents, or even in stoichiometric amounts. Protic solvents showed decreased levels of conversion along the series $\mathrm{H}_{2} \mathrm{O}>\mathrm{MeOH}>\mathrm{EtOH}>i \mathrm{PrOH}$. A model for these solvent effects has been proposed. Water molecules lying in the hy- drophilic outer region force hydrophobic aryl aldehydes into the restricted hydrophobic inner pocket. In this way water promotes the reaction and increases the stereoselectivity. In this sense, our material can be considered a better mimic of natural class I aldolase enzymes, which use an enamine-mediated mechanism in water. Finally, recycling investigations confirmed the usefulness of this catalytic material, which can be easily recovered by simple filtration and reused after few minutes in subsequent cycles without loss in activity. This polystyrene-supported L-proline is currently being used as a catalyst in other L-proline-catalyzed reactions, and further applications and improvements will be presented in the due course.

\section{Experimental Section}

NMR spectra were recorded with a Bruker $300 \mathrm{MHz}$ spectrometer in $\mathrm{CDCl}_{3}$ as solvent. Solid-state ${ }^{13} \mathrm{C}$ MAS NMR spectra were recorded with a Bruker AV 400, $400 \mathrm{MHz}$ spectrometer with samples packed in zirconia rotors spinning at $5 \mathrm{kHz}$. FTIR spectra were recorded with a Shimadzu FTIR 8300 infrared spectrophotometer. Carbon and nitrogen contents were determined by combustion analysis in a Fisons EA 1108 elemental analyzer. Optical rotations were measured in chloroform with a Jasco P1010 polarimeter. Chiral HPLC analyses were performed with a Shimadzu LC-10AD apparatus equipped with a SPD-M10A UV detector and Daicel columns (OD-H, AD-H, AS-H) with hexane/isopropyl alcohol as eluent. Aldol products, except for $(S)-2-[(R)-(3-c h l o r o p h e n y l)(h y-$ droxy)methyl]cyclohexanone (Table 3, Entry 4) and $(S)$-2-[(R)-hydroxy(perfluorophenyl)methyl]cyclohexanone (Table 3, Entry 12), are known compounds (see Table 6 and footnotes) and showed spectroscopic and analytical data in agreement with their structures. Configurations of products were assigned by comparison with literature data (Table 6). Configurations of new products were assigned by analogy.

(2S,4R)-1-(tert-Butoxycarbonyl)-4-(4-vinylbenzyloxy)pyrrolidine-2carboxylic Acid (1): A solution of trans-Boc-4-hydroxy-L-proline $(2.0 \mathrm{~g}, 8.65 \mathrm{mmol})$ in anhydrous THF $(30 \mathrm{~mL})$ was added dropwise, under argon, at $0{ }^{\circ} \mathrm{C}$ to a suspension of $\mathrm{NaH}(60 \%$ mineral oil, $751 \mathrm{mg}, 18.77 \mathrm{mmol})$ in anhydrous THF $(20 \mathrm{~mL})$. The mixture was stirred at r.t. for $1 \mathrm{~h}$, and 18-crown-6 (228 mg, $0.86 \mathrm{mmol})$ and 4chloromethylstyrene $(90 \%, 3.66 \mathrm{~g}, 21.6 \mathrm{mmol})$ were then added. The mixture was stirred for $1 \mathrm{~h}$ at r.t., and then at $50{ }^{\circ} \mathrm{C}$ overnight. After cooling to r.t., water $(100 \mathrm{~mL})$ was added. The aqueous phase was extracted with cyclohexane $(2 \times 250 \mathrm{~mL})$ in order to remove the unreacted 4-chloromethylstyrene. The aqueous phase was acidified at $\mathrm{pH} 2-3$ by adding a solution of $\mathrm{KHSO}_{4}(2 \mathrm{~N})$, and was then extracted with ethyl acetate $(3 \times 100 \mathrm{~mL})$. The organic phase was dried $\left(\mathrm{MgSO}_{4}\right)$ and concentrated under reduced pressure to give compound 1 as a pale yellow, viscous oil $(2.151 \mathrm{~g}, 84 \%)$. [ $\alpha]_{\mathrm{D}}^{28}=$ $-61.0\left(c=0.60, \mathrm{CHCl}_{3}\right) .{ }^{1} \mathrm{H}$ NMR $\left(300 \mathrm{MHz}, \mathrm{CDCl}_{3}\right): \delta=1.45(\mathrm{~s}$, $9 \mathrm{H}), 2.05-2.50(\mathrm{~m}, 2 \mathrm{H}, 3-\mathrm{H}), 3.60-3.78$ (m, $2 \mathrm{H}, 5-\mathrm{H}), 4.15-4.25$ (m, $1 \mathrm{H}, 4-\mathrm{H}), 4.37-4.60\left(\mathrm{~m}, 3 \mathrm{H}, 2-\mathrm{H}\right.$ and $\left.\mathrm{CH}_{2} \mathrm{O}\right), 5.25(\mathrm{~d}, J=$ $10.8 \mathrm{~Hz}, 1 \mathrm{H}, H \mathrm{HC}=\mathrm{CH}), 5.75(\mathrm{~d}, J=17.6 \mathrm{~Hz}, 1 \mathrm{H}, \mathrm{H} H \mathrm{C}=\mathrm{CH})$, $6.72(\mathrm{dd}, J=10.8$ and $17.6 \mathrm{~Hz}, 1 \mathrm{H}, \mathrm{HHC}=\mathrm{CH}), 7.28$ and $7.40(\mathrm{~d}$, $J=8.1 \mathrm{~Hz}$, each $2 \mathrm{H}, \mathrm{ArH}), 10.22$ (br. s, $1 \mathrm{H}, \mathrm{OH}$ ) ppm. ${ }^{13} \mathrm{C} \mathrm{NMR}$ (75 MHz, $\mathrm{CDCl}_{3}$ ): (two rotamers): $\delta=28.2,28.3,35.1,36.6,51.4$, 52.0, 58.1, 70.7, 70.9, 76.0, 76.6, 80.6, 81.0, 113.9, 114.5, 126.3, $126.5,127.8,128.8,136.2,136.4,137.2,137.3,154.1,155.4,176.7$, $178.0 \mathrm{ppm}$. IR (liquid film): $\tilde{v}=3450,2626,1700,1674,1418 \mathrm{~cm}^{-1}$. $\mathrm{C}_{19} \mathrm{H}_{25} \mathrm{NO}_{5}$ (347.41): calcd. C 65.69, H 7.25, N 4.03; found $\mathrm{C}$ 65.77, H 7.33, N 4.10. 
Polystyrene-Supported L-Proline (2): Mercaptomethyl polystyrene was added $(0.965 \mathrm{~g}, 2.4 \mathrm{mmol})$ to a degassed solution of compound $1(2.515 \mathrm{~g}, 7.24 \mathrm{mmol})$ and AIBN $(0.024 \mathrm{~g}, 0.145 \mathrm{mmol})$ in toluene $(30 \mathrm{~mL})$. The mixture was stirred at $110{ }^{\circ} \mathrm{C}$ overnight under argon. After cooling to r.t. the resin was filtered and washed with toluene and acetonitrile. A brilliant yellow resin was obtained $(1.99 \mathrm{~g})$. From the weight increase $(1025 \mathrm{mg})$ it was calculated that $2.94 \mathrm{mmol}$ of monomer has been covalently attached to the resin. The higher content with respect to the mercaptomethyl groups may be ascribed to the formation of short polystyrenic chains. ${ }^{13} \mathrm{C}$ MAS NMR (400 MHz): $\delta=28.8,40.5,59.1,128.5,145.2,185.5 \mathrm{ppm}$. IR: $\tilde{v}=3438,3053,3027,2980,1940,1904,1748,1701,1512,1397$, $1363,1156,1084,819,757,699 \mathrm{~cm}^{-1}$. Elemental analysis found: C 75.54, H 7.25, N 1.96, S 4.00.

A portion of this resin (1.76 g) was suspended in dichloromethane/ trifluoroacetic acid $(8 \mathrm{~mL} / 2 \mathrm{~mL})$. The resin became red and was stirred at r.t. for $3 \mathrm{~h}$. After this period, the resin was filtered and washed with $\mathrm{MeOH} / \mathrm{Et}_{3} \mathrm{~N}$ 98:2 $(100 \mathrm{~mL})$, water $(100 \mathrm{~mL})$, and di- ethyl ether $(100 \mathrm{~mL})$. The brilliant yellow resin was dried at $40{ }^{\circ} \mathrm{C}$ for $24 \mathrm{~h}(1.54 \mathrm{~g})$. The weight difference corresponds to the amount of Boc removed, which is identical to the amount of available proline $\left(2.2 \mathrm{mmol} / 1.54 \mathrm{~g}=1.43 \mathrm{mmol} \mathrm{g}^{-1}\right) .{ }^{13} \mathrm{C}$ MAS NMR (400 MHz): $\delta=30.6,40.0,59.7,128.0,145.2,185.5$ ppm. IR: $\tilde{v}=$ 3410, 3060, 3024, 2918, 2850, 1944, 1904, 1631, 1512, 1492, 1450, $1360,1202,1079,1016,820,753,696 \mathrm{~cm}^{-1}$. Elemental analysis found: C 75.41, H 7.06, N 1.96, S 4.51 .

Typical Procedure for Aldol Reaction: Catalyst $\mathbf{2}$ was added $(0.04 \mathrm{mmol})$ to a mixture of the corresponding aldehyde $(0.4 \mathrm{mmol})$ and ketone $(2.0 \mathrm{mmol})$ in distilled water $(0.14 \mathrm{~mL})$, and the reaction mixture was stirred at r.t. The reaction was quenched by adding ethyl acetate and, upon filtration, the catalyst was washed thoroughly with ethyl acetate and methanol. The organic layers were collected and, after evaporation of solvent, the crude product was checked by ${ }^{1} \mathrm{H}$ NMR spectroscopy and HPLC, and was then purified by chromatography (petroleum ether/ethyl acetate).

Table 6. Selected ${ }^{1} \mathrm{H}$ NMR spectroscopic data for diastereoisomers and HPLC data for enantiomers.

\begin{tabular}{|c|c|c|c|c|c|c|c|c|c|}
\hline \multirow[t]{2}{*}{ Entry } & \multirow[t]{2}{*}{ Compound } & \multicolumn{2}{|c|}{ 'H NMR } & \multicolumn{6}{|c|}{ HPLC } \\
\hline & & $\begin{array}{c}s y n \\
l^{\prime} \mathrm{H} \\
{[\mathrm{ppm}]}\end{array}$ & $\begin{array}{c}\text { anti } \\
1 \cdot \mathrm{H} \\
{[\mathrm{ppm}]}\end{array}$ & Column & $\begin{array}{c}\text { Eluent } \\
\text { (hexane/ } \\
\text { iPrOHI) }\end{array}$ & $\begin{array}{c}\text { Flow } \\
{[\mathrm{mL} / \mathrm{min}]}\end{array}$ & $\begin{array}{c}\lambda \\
{[\mathrm{nm}]}\end{array}$ & $\begin{array}{l}t_{R} \\
\text { Major } \\
{[\mathrm{min}]}\end{array}$ & $\begin{array}{c}t_{\mathrm{R}} \\
\text { Minor } \\
{[\mathrm{min}]}\end{array}$ \\
\hline $1^{\text {[a] }}$ & & 5.4 & 4.8 & AS-H & $90: 10$ & 0.5 & 238 & 26.7 & 29.6 \\
\hline $2^{[a, b]}$ & & 5.4 & 4.8 & AS-HI & $80: 20$ & 1.0 & 264 & 21.2 & 19.2 \\
\hline $3^{|\mathrm{a}|}$ & & 5.5 & 4.9 & AS-HI & $90: 10$ & 0.5 & 218 & 87.9 & 94.8 \\
\hline $4^{[\mathrm{a}, c]}$ & & 5.5 & 4.9 & AS-H & $90: 10$ & 0.5 & 217 & 28.4 & 30.2 \\
\hline $5^{|a|}$ & & 5.6 & 5.0 & AS-H & $90: 10$ & 0.5 & 230 & 86.8 & 75.2 \\
\hline $6^{[b]}$ & & 5.3 & 4.8 & $\mathrm{OD}-\mathrm{H}$ & $95: 5$ & 0.5 & 217 & 12.4 & 15.9 \\
\hline $7^{|x|}$ & & 5.4 & 4.8 & AS-H & $90: 10$ & 0.5 & 219 & 14.3 & 23.1 \\
\hline $8^{[\mathrm{d}]}$ & & 5.7 & 5.3 & $\mathrm{OD}-\mathrm{H}$ & $95: 5$ & 1.0 & 212 & 10.1 & 13.5 \\
\hline
\end{tabular}


Table 6. (Continued)

\begin{tabular}{|c|c|c|c|c|c|c|c|c|}
\hline \multirow[t]{2}{*}{ Entry } & \multirow[t]{2}{*}{ Compound } & 'H NMR & \multicolumn{6}{|c|}{ HPLC } \\
\hline & & $\begin{array}{cc}\operatorname{syn} & \text { anti } \\
1^{\prime} \mathrm{H} & 1^{\prime} \mathrm{H} \\
{[\mathrm{ppm}]} & {[\mathrm{ppm}]}\end{array}$ & Column & $\begin{array}{l}\text { Eluent } \\
\text { (hexane/ } \\
i \mathrm{PrOH}) \\
\end{array}$ & $\begin{array}{l}\text { Flow } \\
{[\mathrm{mL} / \mathrm{min}}\end{array}$ & $\begin{array}{c}\lambda \\
{[\mathrm{nm}]} \\
\end{array}$ & $\begin{array}{l}t_{R} \\
\text { Major } \\
{[\mathrm{min}]} \\
\end{array}$ & $\begin{array}{c}t_{\mathrm{R}} \\
\text { Minor } \\
{[\text { [min] }}\end{array}$ \\
\hline
\end{tabular}
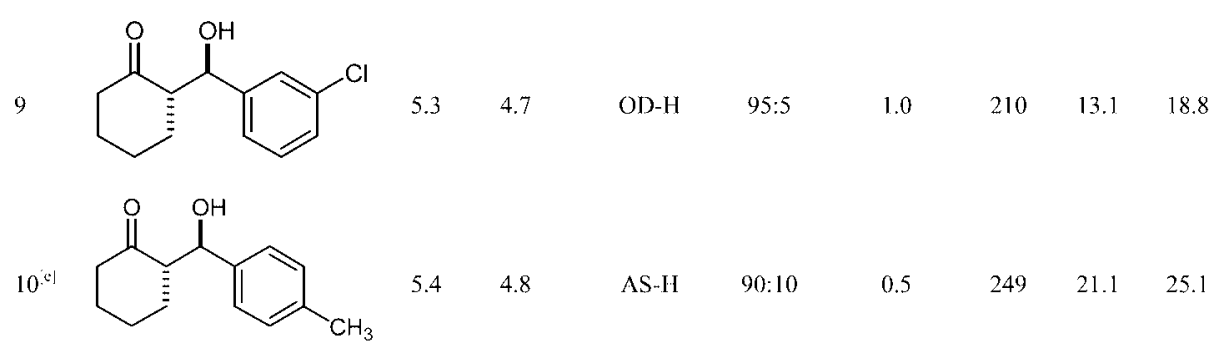<smiles>CC(=O)CC(O)c1ccc([N+](=O)[O-])cc1</smiles>

AS-H $\quad 70: 30 \quad 1.0 \quad 255 \quad 12.7 \quad 17.1$<smiles>O=C1CCCC[C@H]1C(O)c1ccc2ccccc2c1</smiles><smiles>O=C1CCCC[C@H]1C(O)c1ccco1</smiles><smiles>O=C1CCC[C@H]1C(O)c1ccc([N+](=O)[O-])cc1</smiles><smiles>N#Cc1ccc(C(O)[C@@H]2CCCC2=O)cc1</smiles><smiles>O=C1CCCC[C@H]1C(O)c1c(F)c(F)c(F)c(F)c1C(O)c1ccc([N+](=O)[O-])cc1</smiles>

[a] Ref. ${ }^{[28 a]}$ [b] Ref. ${ }^{[43]}$ [c] Ref. ${ }^{[44]}$ [d] Ref. ${ }^{[45]}$ [e] Ref. ${ }^{[46]}$ [f] Ref. ${ }^{[28 b]}$ [g] Ref. ${ }^{[47]}$ [h] Ref. ${ }^{[35]}$ [i] Ref. ${ }^{[48]}$ [j] Ref. ${ }^{[27 d]}$

(S)-2-[(R)-(3-Chlorophenyl)(hydroxy)methyl]cyclohexanone: Yield: $68.7 \mathrm{mg}, 72 \%$. M.p. $38-40{ }^{\circ} \mathrm{C}$. $[\alpha]_{\mathrm{D}}^{25}=+16.20\left(c=1.16, \mathrm{CHCl}_{3}\right)$. ${ }^{1} \mathrm{H}$ NMR $\left(300 \mathrm{MHz}, \mathrm{CDCl}_{3}\right): \delta=1.20-1.30(\mathrm{~m}, 1 \mathrm{H}), 1.43-1.75$ (m, $4 \mathrm{H}), 1.99-2.07$ (m, $1 \mathrm{H}), 2.23-2.55$ (m, $3 \mathrm{H}), 3.93$ (s, $1 \mathrm{H}), 4.70$ $(\mathrm{d}, J=8.7 \mathrm{~Hz}, 1 \mathrm{H}), 7.08-7.23(\mathrm{~m}, 4 \mathrm{H}) \mathrm{ppm} .{ }^{13} \mathrm{C} \mathrm{NMR}(75 \mathrm{MHz}$, $\left.\mathrm{CDCl}_{3}\right): \delta=24.7,27.7,30.8,42.7,57.2,74.3,125.3,127.1,128.1$, 129.6, 134.3, 143.0, $215.3 \mathrm{ppm}$. IR (film): $\tilde{v}=3442,1696 \mathrm{~cm}^{-1}$. $\mathrm{C}_{13} \mathrm{H}_{15} \mathrm{ClO}_{2}$ (238.71): calcd. C 65.41, H 6.33; found $\mathrm{C} 65.55, \mathrm{H}$ 6.35 (Table 3, Entry 4).
(S)-2-[(R)-Hydroxy(perfluorophenyl)methyl]cyclohexanone: Yield $103.6 \mathrm{mg}, 88 \%$. M.p. $85-87^{\circ} \mathrm{C}$. $[\alpha]_{\mathrm{D}}^{25}=-14.99\left(c=1.78, \mathrm{CHCl}_{3}\right)$. ${ }^{1} \mathrm{H}$ NMR $\left(300 \mathrm{MHz}, \mathrm{CDCl}_{3}\right): \delta=1.23-1.38(\mathrm{~m}, 1 \mathrm{H}), 1.55-1.74$ (m, $3 \mathrm{H}), 1.81-1.89(\mathrm{~m}, 1 \mathrm{H}), 2.08-2.16(\mathrm{~m}, 1 \mathrm{H}), 2.31-2.44(\mathrm{~m}, 2$ H), 2.47-2.54 (m, 1 H), 2.95-3.05 (m, $1 \mathrm{H}), 4.28$ (brs, $1 \mathrm{H}), 5.31$ $(\mathrm{d}, J=9.6 \mathrm{~Hz}, 1 \mathrm{H}) \mathrm{ppm} .{ }^{13} \mathrm{C} \mathrm{NMR}\left(75 \mathrm{MHz}, \mathrm{CDCl}_{3}\right): \delta=24.9$, 27.9, 30.5, 42.7, 54.6, 66.3, 114-148 (multiplet, $\mathrm{C}_{6} \mathrm{~F}_{5}$ ), $214.5 \mathrm{ppm}$. IR (Nujol): $\tilde{v}=3411,1706 \mathrm{~cm}^{-1} \cdot \mathrm{C}_{13} \mathrm{H}_{11} \mathrm{~F}_{5} \mathrm{O}_{2}$ (294.22): calcd. $\mathrm{C}$ 53.07, H 3.77; found C 53.17, H 3.78 (Table 3, Entry 12). 


\section{Acknowledgments}

Financial support from the University of Palermo (Funds for selected topics) and the Italian MIUR within the National Project "Catalizzatori, metodologie e processi innovativi per il regio- e stereocontrollo delle sintesi organiche" is gratefully acknowledged. The authors thank Dr. Carmela Aprile for SEM images.

[1] a) G. Guillena, D. J. Ramón, Tetrahedron: Asymmetry 2006, 17, 1465-1492; b) P. I. Dalko, L. Moisan, Angew. Chem. Int. Ed. 2004, 43, 5138-5175; c) R. O. Duthaler, Angew. Chem. Int. Ed. 2003, 42, 975-978; d) A. Berkessel, H. Gröger (Eds.), Asymmetric Organocatalysis: From Biomimetic Concepts to Applications in Asymmetric Synthesis, Wiley-VCH, Weinheim, 2005; e) Special issue on organocatalysis: Acc. Chem. Res. 2004, 37, 631847; f) Special issue on organocatalysis: Adv. Synth. Catal. 2004, 346, 1007-1249; g) Special issue on organocatalysis: Tetrahedron 2006, 62, 243-502.

[2] Review on proline-catalyzed reactions: a) B. List, Tetrahedron 2002, 58, 5573-5590; b) E. R. Jarvo, S. J. Miller, Tetrahedron 2002, 58, 2481-2495; c) W. Notz, F. Tanaka, C. F. Barbas III, Acc. Chem. Res. 2004, 37, 580-591.

[3] T. Bui, C. F. Barbas III, Tetrahedron Lett. 2000, 41, 6951-6954.

[4] a) B. List, R. A. Lerner, C. F. Barbas III, J. Am. Chem. Soc. 2000, 122, 2395-2396; b) K. Sakthivel, W. Notz, T. Bui, C. F. Barbas III, J. Am. Chem. Soc. 2001, 123, 5260-5267. Selected recent examples on proline-catalyzed aldol reactions: c) J. T. Suri, S. Mitsumori, K. Albertshofer, F. Tanaka, C. F. Barbas III, J. Org. Chem. 2006, 71, 3822-3828; d) C. Grondal, D. Enders, Tetrahedron 2006, 62, 329-337; e) J. T. Suri, D. B. Ramachary, C. F. Barbas III, Org. Lett. 2005, 7, 1383-1385; f) I. Ibrahem, A. Córdova, Tetrahedron Lett. 2005, 46, 33633367; g) R. I. Storer, D. W. C. MacMillan, Tetrahedron 2004, $60,7705-7714 ;$ h) J. Casas, H. Sundén, A. Córdova, Tetrahedron Lett. 2004, 45, 6117-6119; i) Q. Pan, B. Zou, Y. Wang, D. Ma, Org. Lett. 2004, 6, 1009-1012; j) A. B. Northrup, I. K. Mangion, F. Hettche, D. W. C. MacMillan, Angew. Chem. Int. Ed. 2004, 43, 2152-2154; k) C. Allemann, R. Gordillo, F. R. Clemente, P. H.-Y. Cheong, K. N. Houk, Acc. Chem. Res. 2004, $37,558-569$; 1) R. Thayumanavan, F. Tanaka, C. F. Barbas III, Org. Lett. 2004, 6, 3541-3544; m) C. Pidathala, L. Hoang, N. Vignola, B. List, Angew. Chem. Int. Ed. 2003, 42, 2785-2788.

[5] a) B. List, J. Am. Chem. Soc. 2000, 122, 9336-9337; b) A. Córdova, W. Notz, G. Zhong, J. M. Betancort, C. F. Barbas III, J. Am. Chem. Soc. 2002, 124, 1842-1843; c) B. List, P. Pojarliev, W. T. Biller, H. J. Martin, J. Am. Chem. Soc. 2002, 124, 827-833; d) W. Notz, F. Tanaka, S. Watanabe, N. S. Chowdari, J. M. Turner, R. Thayumanavan, C. F. Barbas III, J. Org. Chem. 2003, 68, 9624-9634; e) N. S. Chowdari, D. B. Ramachary, C. F. Barbas III, Synlett 2003, 1906-1909; f) N. S. Chowdari, J. T. Suri, C. F. Barbas III, Org. Lett. 2004, 6, 2507-2510.

[6] a) B. List, P. Pojarliev, H. J. Martin, Org. Lett. 2001, 3, 2423 2425; b) J. M. Betancort, C. F. Barbas III, Org. Lett. 2001, 3, 3737-3740; c) D. Enders, A. Seki, Synlett 2002, 26-28; d) D. Gryko, Tetrahedron: Asymmetry 2005, 16, 1377-1383; e) I. K. Mangion, D. W. C. MacMillan, J. Am. Chem. Soc. 2005, 127, 3696-3697.

[7] a) A. Bøgevig, K. Juhl, N. Kumaragurubaran, W. Zhuang, K. N. Jørgensen, Angew. Chem. Int. Ed. 2002, 41, 1790-1793; b) B. List, J. Am. Chem. Soc. 2002, 124, 5656-5657; c) J. T. Suri, D. D. Steiner, C. F. Barbas III, Org. Lett. 2005, 7, 38853888 .

[8] a) G. Sabitha, N. Fatima, E. V. Reddy, J. S. Yadav, Adv. Synth. Catal. 2005, 347, 1353-1355; b) R. Thayumanavan, B. Dhevalapally, K. Sakthivel, F. Tanaka, C. F. Barbas III, Tetrahedron Lett. 2002, 43, 3817-3820; c) D. B. Ramachary, N. S. Chowdari, C. F. Barbas III, Tetrahedron Lett. 2002, 43, 6743-6746.

[9] a) M. Shi, J. K. Jiang, C. Q. Li, Tetrahedron Lett. 2002, 43, 127-130; b) S. H. Chen, B. C. Hong, C. F. Su, S. Sarshar, Tetra- hedron Lett. 2005, 46, 8899-8903; c) J. E. Imbriglio, M. M. Vasbinder, S. J. Miller, Org. Lett. 2003, 5, 3741-3743.

[10] N. Utsumi, H. Zhang, F. Tanaka, C. F. Barbas III, Angew. Chem. Int. Ed. 2007, 46, 1878-1880.

[11] J. Wang, H. Li, Y. Mei, B. Lou, D. Xu, D. Xie, H. Guo, W. Wang, J. Org. Chem. 2005, 70, 5678-5687.

[12] G. Zhong, Angew. Chem. Int. Ed. 2003, 42, 4247-4250.

[13] M. P. Brochu, S. P. Brown, D. W. C. MacMillan, J. Am. Chem. Soc. 2004, 126, 4108-4109.

[14] a) S. Wallbaum, J. Martens, Tetrahedron: Asymmetry 1993, 3 , 1475-1504; b) M. T. Rispens, C. Zondervan, B. L. Feringa, Tetrahedron: Asymmetry 1995, 6, 661-664.

[15] R. Marhrwald (Ed.), Modern Aldol Reactions, Wiley-VCH, Weinheim, 2004, vols 1-2.

[16] C.-H. Wong, R. L. Halcomb, Y. Ichikawa, T. Kajimoto, Angew. Chem. Int. Ed. Engl. 1995, 34, 412-432.

[17] a) F. Cozzi, Adv. Synth. Catal. 2006, 348, 1367-1390; b) M. Benaglia, A. Puglisi, F. Cozzi, Chem. Rev. 2003, 103, 34013429; c) A. Corma, H. Garcia, Adv. Synth. Catal. 2006, 348 , 1391-1412.

[18] a) P. Kotrusz, I. Kmentová, B. Gotov, Š. Toma, E. Solčániová, Chem. Commun. 2002, 2510-2511; b) T.-P. Loh, L.-C. Feng, H.-Y. Yang, J.-Y. Yang, Tetrahedron Lett. 2002, 43, 8741-8743.

[19] A. Córdova, Tetrahedron Lett. 2004, 45, 3949-3952.

[20] W. Miao, T.-H. Chan, Adv. Synth. Catal. 2006, 348, 1711-1718.

[21] S. Chandrasekhar, N. Ramakrishna Reddy, S. Shameen Sultana, Ch. Narsihmulu, K. Venkatram Reddy, Tetrahedron 2006, $62,338-345$.

[22] a) M. Gruttadauria, S. Riela, P. Lo Meo, F. D'Anna, R. Noto, Tetrahedron Lett. 2004, 45, 6113-6116; b) M. Gruttadauria, S. Riela, C. Aprile, P. Lo Meo, F. D'Anna, R. Noto, Adv. Synth. Catal. 2006, 348, 82-92.

[23] a) M. Benaglia, M. Cinquini, F. Cozzi, A. Puglisi, G. Celentano, Adv. Synth. Catal. 2002, 344, 533-542; b) M. Benaglia, G. Celentano, F. Cozzi, Adv. Synth. Catal. 2001, 343, 171-175.

[24] K. Akagawa, S. Sakamoto, K. Kudo, Tetrahedron Lett. 2005 , 46, 8185-8187.

[25] F. Calderón, R. Fernández, F. Sánchez, A. Fernández-Mayoralas, Adv. Synth. Catal. 2005, 347, 1395-1403.

[26] P. M. Pihko, K. M. Laurikainen, A. Usano, A. I. Nyberg, J. A. Kaavi, Tetrahedron 2006, 62, 317-328.

[27] a) A. I. Nyberg, A. Usanp, P. M. Pihko, Synlett 2004, 18911896; b) S. S. Chimni, D. Mahajan, V. V. Suresh Babu, Tetrahedron Lett. 2005, 46, 5617-5619; c) T. Darbre, M. Machuqueiro, Chem. Commun. 2003, 1090-1091; d) D. A. Ward, V. Jheengut, Tetrahedron Lett. 2004, 45, 8347; e) Y.-S. Wu, W.-Y. Shao, C.Q. Zheng, Z.-L. Huang, J. Cai, Q.-Y. Deng, Helv. Chim. Acta 2004, 87, 1377.

[28] a) N. Mase, Y. Nakai, N. Ohara, H. Yoda, K. Takabe, F Tanaka, C. F. Barbas III, J. Am. Chem. Soc. 2006, 128, 734 735 ; b) Y. Hayashi, T. Sumiya, J. Takahashi, H. Gotoh, T. Urushima, M. Shoji, Angew. Chem. Int. Ed. 2006, 45, 958-961.

[29] A. P. Brogan, T. J. Dickerson, K. D. Janda, Angew. Chem. Int. Ed. 2006, 45, 8100-8102.

[30] Y. Hayashi, Angew. Chem. Int. Ed. 2006, 45, 8103-8104.

[31] D. G. Blackmond, A. Armstrong, V. Coombe, A. Wells, Angew. Chem. Int. Ed. 2007, 46, 3798-3800.

[32] F. Giacalone, M. Gruttadauria, A. Mossuto Marculescu, R. Noto, Tetrahedron Lett. 2007, 48, 255-259.

[33] D. Font, C. Jimeno, M. A. Pericàs, Org. Lett. 2006, 8, 4653 4655.

[34] B. List, P. Pojarliev, W. T. Biller, J. Am. Chem. Soc. 2002, 124 , 827-833.

[35] Y.-S. Wu, Y. Chen, D.-S. Deng, J. Cai, Synlett 2005, 1627-1629.

[36] In our previous communication (ref. ${ }^{[32]}$ ) we observed decreased levels of conversion after four cycles. In that case we washed the resin with acetone. By avoiding the use of acetone, no decreased levels of conversion were observed. 
[37] a) T. J. Dickerson, K. D. Janda, J. Am. Chem. Soc. 2002, 124, 3220-3221; b) F. Tanaka, R. Thayumanavan, N. Mase, C. F. Barbas III, Tetrahedron Lett. 2004, 45, 325-328.

[38] M. C. Pirrung, Chem. Eur. J. 2006, 12, 1312-1317.

[39] A. Córdova, W. Zou, I. Ibrahem, E. Reyes, M. Engqvist, W.W. Liao, Chem. Commun. 2005, 3586-3588.

[40] U. M. Lindström, F. Andersson, Angew. Chem. Int. Ed. 2006, $45,548-551$.

[41] S. Bahmanyar, K. N. Houk, H. J. Martin, B. List, J. Am. Chem. Soc. 2003, 125, 2475-2479.

[42] a) U. M. Lindström, Chem. Rev. 2002, 102, 2751-2772; b) T. P. Loh, J. M. Huang, K. C. Xu, S. H. Goh, J. J. Vittal, Tetrahedron Lett. 2000, 41, 6511-6515; c) C. Denis, B. Laignel, D. Plusquellec, J.-Y. Le Marouille, A. Botrel, Tetrahedron Lett. 1996, 37, 53-56; d) A. Lubineau, J. Augé, N. Lubin, J. Chem. Soc. Perkin Trans. 1 1990, 3011-3015; e) E. Brandes, P. A.
Grieco, P. Garner, J. Chem. Soc. Chem. Commun. 1988, 500502; f) Y. Hiraki, A. Tai, Chem. Lett. 1982, 11, 341-344.

[43] A. Yanagisawa, H. Takahashi, T. Arai, Chem. Commun. 2004, $580-581$.

[44] P. Dziedzic, W. Zou, J. Hafren, A. Cordova, Org. Biomol. Chem. 2006, 4, 38-40.

[45] J.-R. Chen, H.-H. Lu, X.-Y. Li, L. Cheng, J. Wan, W.-J. Xiao, Org. Lett. 2005, 7, 4543-4545.

[46] A. Yanagisawa, Y. Matsumoto, K. Asakawa, H. Yamamoto, J. Am. Chem. Soc. 1999, 121, 892-893.

[47] Z. Jiang, Z. Liang, X. Wu, Y. Lu, Chem. Commun. 2006, 28012803.

[48] P. Dinér, M. Amedjkouh, Org. Biomol. Chem. 2006, 4, $2091-$ 2096.

Received: June 26, 2007

Published Online: August 28, 2007 